JPP IPTEK Mei 2019, Vol. 3, No. 1

ISSN 2620-7745 (online)

https://dx.doi.org/10.31284/j.jpp-iptek.2019.v3i1.481

\title{
Pemberdayaan Masyarakat Desa Sumberdadi dengan Pelatihan Hidroponik dan Pupuk Organik
}

\author{
Aldila Wanda Nugraha \\ Pendidikan IPA, STKIP PGRI Tulungagung \\ aldila@stkippgritulungagung.ac.id
}

\begin{abstract}
Agriculture is a potential that exists in Sumberdadi village. The community in Sumberdadi village are citizens that have productive age, who can't manage time in an optimum way. Community empowerment in Sumberdadi village Sumbergempol Tulungagung Subdistrict is caused by productive-age citizens that can't use time well, low utilization of narrow yard in the community house, low knowledge about hydroponic planting patterns, and lack of knowledge about organic fertilizer production. The purpose of this program was to increase the knowledge, skills, and productivity of hydroponic products and organic fertilizers. The output of this program are (1) increasing knowledge and skills, awareness and motivating target partners, especially groups of mothers in the use of vacant land / yard as a food producer / food security and alternative sources of family income; (2) installation of simple hydroponic techniques and their maintenance that can be applied by the community; and (3) able to produce organic fertilizers for hydroponic plants and plants by other conventional methods. The participative methods are used to involve partners actively in implementing the hydroponic techniques and production of organic fertilizers. The results of the activities that have been carry out include the introduction of hydroponic installation methods and techniques, knowledge of tools and materials, and how to produce organic fertilizers and their applications. The program has been assisted the partner in solving the problems and increasing the production level.
\end{abstract}

Keywords: Hydroponic, Organic fertilizer, Community partnership program, Production technology

\begin{abstract}
ABSTRAK
Pertanian merupakan potensi yang ada di Desa Sumberdadi. Mitra sasaran di Desa Sumberdadi adalah warga usia produktif yang kurang memanfaatkan manajemen waktu dengan optimal. Pemberdayaan masyarakat di Desa Sumberdadi Kecamatan Sumbergempol Tulungagung ini dilatarbelakangi masalah warga usia kerja yaitu waktu luang yang kurang produktif, rendahnya pemanfaatan lahan pekarangan sempit di rumah waga mitra, pengetahuan yang rendah tentang pola tanam hidroponik, serta minimnya pengetahuan mitra sasaran tentang produksi pupuk organik. Pemberdayaan masyarakat ini bertujuan untuk meningkatkan ketrampilan, pengetahuan serta produktivitas produk hidroponik dan pupuk organik. Target luaran dalam kegiatan ini adalah (1) meningkatnya pengetahuan dan ketrampilan, kesadaran serta memotivasi mitra sasaran khususnya kelompok ibu-ibu dalam pemanfaatan lahan kosong/ pekarangan sebagai sumber pangan/ketahanan pangan dan sumber alternatif pendapatan keluarga; (2) instalasi teknik hidroponik sederhana dan pemeliharaannya yang dapat diterapkan oleh masyarakat; dan (3) mampu memproduksi pupuk organik untuk tanaman, khususnya hidroponik dan tanaman dengan metode konvensional lain. Metode partisipatif digunakan untuk melibatkan mitra secara aktif dalam pelaksanaan penerapan teknik hidroponik dan produksi pupuk organik. Hasil kegiatan yang sudah dilaksanakan antara lain, introduksi metode dan teknik instalasi hidroponik, pengetahuan alat dan bahan, dan cara produksi pupuk organik serta aplikasinya. Program pengabdian masyarakat yang sudah dilaksanakan ini membantu mitra sasaran dalam menyelesaikan permasalahan dan meningkatkan produktivitas mitra sasaran.
\end{abstract}

Kata kunci: Hidroponik, Pupuk organik, Pengabdian kepada masyarakat, Teknologi produksi

\section{PENDAHULUAN}

Pertanian merupakan sektor fundamental bagi bangsa Indonesia yang dikenal sebagai negara agraris. Dalam peningkatan kualitas hasil pertanian dan pemanfaatan lahan yang tidak dipakai oleh masyarakat maka muncul metode pemanfaatan lahan sempit sebagai usaha untuk pemberdayaan masyarakat dengan cara hidroponik (Roidah, 2014). Istilah hidroponik muncul tahun 1936, sebagai penghargaan kepada Dr. W.F. Gericke, seorang agronomis Universitas 
California. Hidroponik atau yang dikenal dengan cara menanam tanaman dengan media cair ataupun tanpa tanah ini sangat membantu penduduk dengan intensitas kerja tinggi namun memiliki lahan minim untuk berkebun. Hidroponik ini dapat dilakukan dalam lahan yang sempit dengan bantuan beberapa media tanam dan cukup mudah dilakukan. Hal ini ditujukan untuk membantu masyarakat agar dapat menanam tumbuhan baik sayuran maupun buah yang menjadi bahan makanan sehari-hari, dengan demikian harapannya adalah masyarakat dapat memenuhi kebutuhan serat dalam tubuhnya dengan mudah dan tercukupi dengan baik.

Kebutuhan pangan bagi masyarakat mengalami fenomena kenaikan konsumsi yang linier dengan pertambahan jumlah penduduk. Namun tidak diikuti dengan penambahan lahan pertanian yang semakin terdegradasi dengan lahan permukiman dan industri. Hal itu semakin menegaskan tentang pentingnya metode hidroponik untuk dijadikan model usaha pertanian. Realita di lapangan berkata bahwa banyak masyarakat yang belum mengetahui seperti apa tanaman hidroponik, masih banyak masyarakat yang enggan untuk melakukan kegiatan berkebun, meskipun banyak masyarakat yang sudah menyadari pentingnya kebutuhan tanaman baik sayuran dan buah bagi kebutuhan hidup (Dwiratna, Widyasanti, dan Rahmah, 2016). Jika masyarakat atau orang dewasa saja belum memiliki kesadaran untuk melakukan kegiatan menanam tumbuhan sendiri maka kemungkinan besar generasi penerusnya juga tidak melakukan. Oleh karena itu sangat diperlukan upaya untuk menyadarkan sikap kepedulian mereka terhadap pentingnya menjaga lingkungan, memenuhi kebutuhan asupan gizi dan serat mereka baik dari sayuran maupun buah (Ashari dan Purwantini, 2012). Upaya peningkatan standar hidup layak dengan mengenalkan hidroponik disertai metode pembuatan pupuk organik demi kelestarian lingkungan. Harapannya adalah setelah mereka mengenal hidroponik ini mereka dapat lebih mencintai lingungan mereka, memberikan kesadaran bagi mereka bahwa menanam tumbuhan itu tidak sulit, menanam tumbuhan itu tidak membutuhkan waktu lama, dan menyenangkan. Hidroponik juga dapat dijadikan mata pencaharian masyarakat yang baru karena menghasilkan produk organik dan ramah lingkungan yang pastinya memiliki nilai ekonomi tinggi.

Berdasarkan analisis situasi yang telah diuraikan, maka diperlukan pemberdayaan masyarakat di bidang hidroponik sebagai salah satu cara mengatasi problem di masyarakat dan pemanfaatan potensi lahan pekarangan sekitar. Diharapkan kegiatan ini dapat meningkatkan wawasan, kreatifitas, dan peningkatan kesejahteraan ekonomi masyarakat.

\section{METODE PELAKSANAAN}

\subsection{Metode Kegiatan}

Sasaran kegiatan adalah ibu-ibu PKK dan bapak-bapak yang kurang produktif di Desa Sumberdadi Tulungagung. Metode kegiatan yang dilakukan untuk keberhasilan tujuan pengabdian kepada masyarakat melalui metode ceramah, diskusi dan praktik langsung di lapangan yang didasari oleh hasil observasi permulaan sebagai landasan penentuan tingkat pemahaman dan wawasan kelompok sasaran mengenai penggunaan lahan pekarangan, cara budidaya hidroponik, pengenalan alat dan bahan, praktek pembuatan pupuk organik dan kuliah umum perubahan pola pikir mitra menjadi seorang wirausahawan, dan komitmen untuk melakukan kegiatan pelestarian lingkungan. Langkah berikutnya dilakukan praktik lapangan berupa penerapan teknologi hidroponik dan pupuk organik dengan bahan-bahan sederhana dan memanfaatkan limbah organik. Penerapan teknologi tersebut dilaksanakan di rumah milik mitra. Persiapan dan pelaksanaan pelatihan dilakukan dengan metode partisipatif dari peserta atau mitra (Sarwono dkk, 2018).

\subsection{Tahapan Kegiatan}

Setelah dilakukan penjajakan melalui diskusi dan survei kepada mitra, kegiatan selanjutnya dari serangkaian pengabdian masyarakat ini adalah pelatihan lapangan bercocok tanam hidroponik dan pembuatan pupuk organik. Kegiatan ini dilakukan di luar ruang dengan berlokasi di pekarangan rumah warga, karena untuk praktik cara bertanam hidroponik dan juga pembuatan pupuk memerlukan ruang yang lantainya tidak licin, dan dekat dengan kran air. Untuk penyampaian materi mengenai teknik hidroponik dilakukan selama dua hari, hari pertama 
dilakukan pada sesi pertama yaitu setelah materi motivasi menjadi wirausaha baru. Pada hari kedua, sesi kedua adalah kegiatan praktik bercocok tanam hidroponik oleh peserta, meliputi kegiatan menyiapkan media tanam, bibit tanaman, pipa paralon, dan pengarahan tindakan selanjutnya yang harus dilakukan perserta setelah bibit disemaikan. Secara singkat, rangkaian kegiatan yang diikuti peserta selama praktik cocok tanam sayuran secara hidroponik (teknik wick) secara sederhana yaitu:

\section{Alat dan bahan:}

1. Pipa paralon berukuran 1,5 meter sebagai penampung nutrisi

2. Net Pot, kain flanel, styrofoam, rockwool, bibit sayuran, nutrisi AB mix

\section{Langkah-langkah:}

a. Paralon diberi lubang dengan diameter sesuai dengan net pot, kemudian potong rockwool berbentuk dadu ukuran $2.5 \times 2.5 \mathrm{~cm}$, kemudian rockwool direndam sebentar dengan air biasa lalu diangkat dan dikibaskan.

b. Membuat lubang untuk benih pada rockwool dengan menggunakan tusuk gigi, kemudian angkat benih dengan tusuk gigi, letakkan pada lubang rockwool yang telah dibuat. Setelah selesai benih ditutupi dengan plastik hitam untuk menghindari cahaya

c. Ketika benih sudah mulah pecah atau sprout, benih dijemur dan disiram secara berkala untuk menjaga agar rockwool tidak kering. Ketika tanaman sudah berdaun empat, sudah bisa diberikan nutrisi

d. Menyiapkan air bersih dalam wadah untuk pemberian nutrisi dengan catatan dalam setiap satu liter air, tambahkan $5 \mathrm{ml}$ Nutrisi A dan $5 \mathrm{ml}$ Nutrisi B. lalu persiapkan netpot dan sumbu, letakkan tanaman diatas sumbu kemudian dimasukkan kedalam lubang paralon.

Untuk selanjutnya langkah-langkah kegiatan pengabdian dapat dilihat pada Gambar 1.

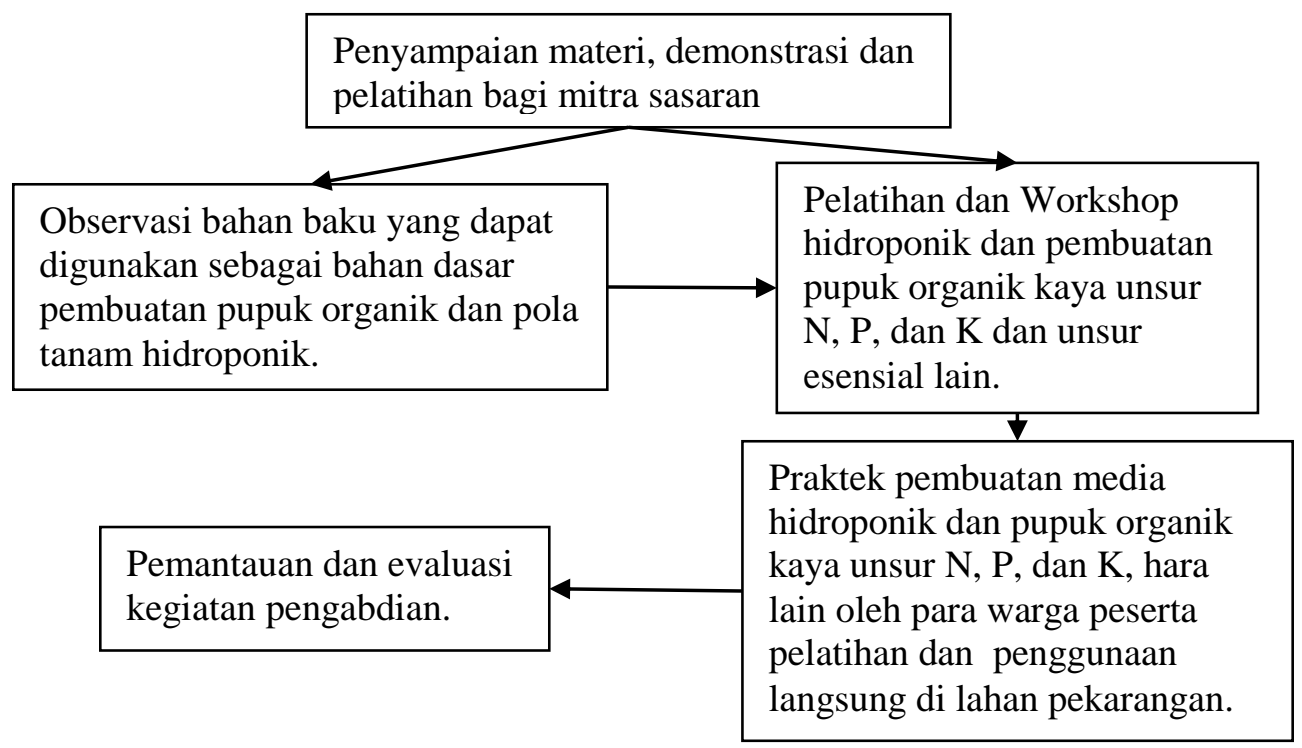

Gambar 1. Langkah-langkah kegiatan pengabdian

\subsection{Faktor Pendukung dan Penghambat}

Faktor di lapangan yang menjadi pendorong keberhasilan kegiatan ini, yaitu bahwa kegiatan ini dirancang dengan keterlibatan yang tinggi dari mitra pengabdian. Permasalahan yang diangkat dan diidentifikasi diperoleh secara langsung sehingga warga sangat antusias ketika mengikuti setiap tahap pengabdian masyarakat meskipun dengan jadwal yang padat.

Narasumber yang memberikan pelatihan dan workshop memiliki kemampuan komunikasi yang sangat baik sehingga bisa menyatu dengan peserta, baik secara formal maupun informal, 
disamping itu yang bersangkutan merupakan orang-orang yang memang menguasai secara keilmuan dan praktik.

Faktor yang menjadi penghambat adalah sarana untuk presentasi yang kurang baik, karena tidak tersedia layar stand untuk menampilan materi presentasi pada hari pertama dan kondisi cuaca yang tidak dapat diprediksi pada saat kegiatan nanti yang dimungkinkan mengganggu konsentrasi peserta. Introduksi metode hidroponik dan pupuk organik sangat berdaya guna penyelesaian kendala yang terjadi di masyarakat selama ini. Pemberdayaan yang dilakukan mampu mengatasi pula masalah limbah domestik organik masyarakat yang selama ini belum dimanfaatkan dan terbuang percuma.

\section{HASIL DAN PEMBAHASAN}

\subsection{Hasil}

Setelah dilakukan observasi melalui diskusi dan survei terhadap mitra, tahap berikutnya dari kegiatan ini yaitu workshop pelatihan bercocok tanam dengan teknik hidroponik, panembuat pupuk organik, kewirausahaan dan pemasaran produk. Kegiatan ini dilaksanakan di outdoor dengan mendirikan tenda pertemuan. Acara dirancang sedemikian rupa karena di lingkungan desa Sumberdadi ini tidak ada gedung atau balai pertemuan, namun hal ini tidak menjadi masalah mengingat untuk praktik cara bertanam dengan teknik hidroponik dan pembuatan pupuk memerlukan tempat yang lantainya tidak licin untuk memenuhi unsur keselamatan kerja, dekat dengan kran air, dan akses mudah ke bahan baku. Pada kegiatan penyampaian materi hidroponik dilakukan selama dua hari, hari pertama dilakukan setelah materi motivasi menjadi wirausaha baru.

Kegiatan hari kedua sesi pertama adalah pelaksanaan praktik bercocok tanam dengan teknik hidroponik oleh peserta dan langsung dibimbing oleh peneliti, meliputi kegiatan menyiapkan media tanam, bibit tanaman, pipa paralon, dan pengarahan tindakan selanjutnya yang harus dilakukan perserta setelah bibit selesai disemaikan. Secara singkat tahapan yang dilakukan oleh peserta selama praktik cocok tanam sayuran secara hidroponik (teknik wick) secara sederhana:

\section{Alat dan bahan:}

1. Pipa paralon berukuran 1,5 meter sebagai penampung nutrisi

2. Net Pot, kain flanel, styrofoam, rockwool, bibit sayuran, nutrisi AB mix

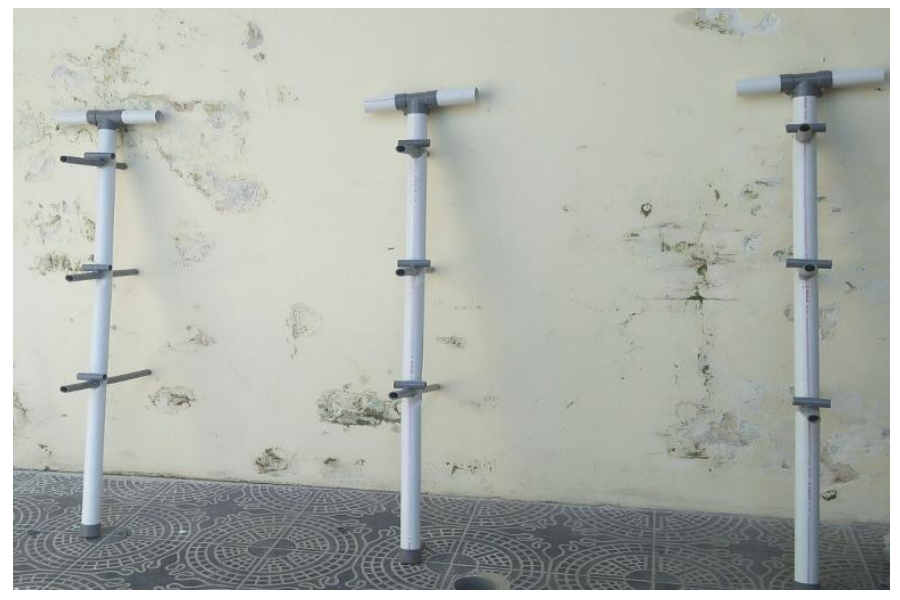

Gambar 2. Instalasi dasar pipa nutrisi hidroponik

Langkah-langkah:

a. Paralon diberi lubang dengan diameter sesuai dengan net pot, kemudian potong rockwool berbentuk dadu ukuran $2.5 \times 2.5 \mathrm{~cm}$, kemudian rockwool direndam sebentar dengan air biasa lalu diangkat dan dikibaskan. 
b. Membuat lubang untuk benih pada rockwool dengan menggunakan tusuk gigi, kemudian angkat benih dengan tusuk gigi, letakkan pada lubang rockwool yang telah dibuat. Setelah selesai benih ditutupi dengan plastik hitam untuk menghindari cahaya

c. Ketika benih sudah mulah pecah atau sprout, benih dijemur dan disiram secara berkala untuk menjaga agar rockwool tidak kering. Ketika tanaman sudah berdaun empat, sudah bisa diberikan nutrisi

d. Menyiapkan air bersih dalam wadah untuk pemberian nutrisi dengan catatan dalam setiap satu liter air, tambahkan 5ml Nutrisi A dan 5ml Nutrisi B.Kemudian siapkan netpot dan sumbu, dan letakkan tanaman diatas sumbu kemudian dimasukkan kedalam lubang paralon.

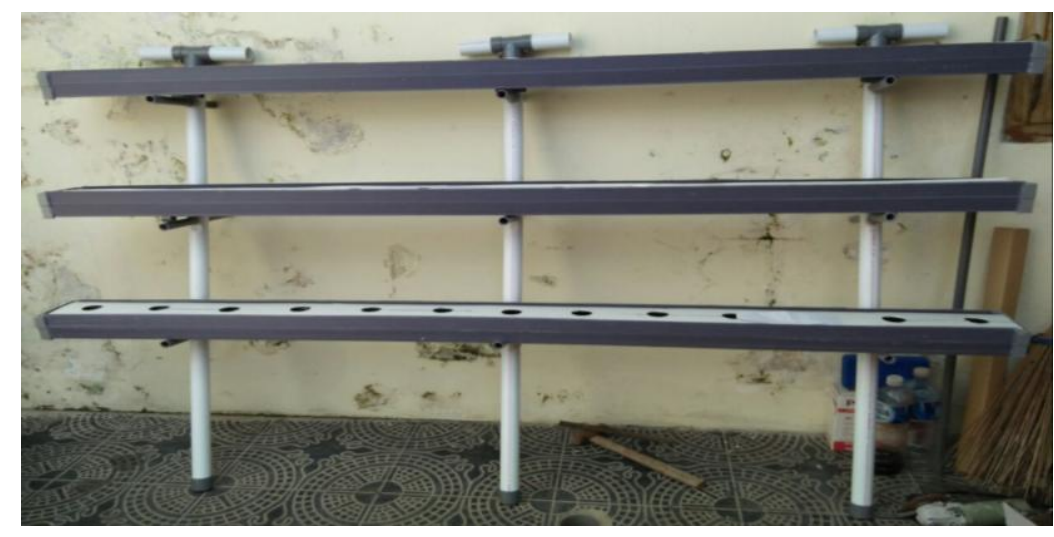

Gambar 3. Instalasi pipa nutrisi hidroponik teknik Wick

Pada hari kedua, kegiatan dimulai lebih awal yaitu pukul 07.30, hal ini memungkinkan peserta memiliki waktu untuk praktik dan berinterkasi langsung dengan narasumber. Pesera sangat antusias, hal ini terlihat dari persiapan mereka meliputi catatan dan membawa sisa potongan sayur, beberapa bahan tertentu yang dimilikinya di rumah untuk ditanyakan kepada nara sumber, kemungkinan bahan tersebut bisa dimanfaatkan baik sebagai media tanam maupun sebagai bahan pembuat nurtrisi organik tanaman hidroponiknya. Bukti antusiasme mitra mengikuti pelatihan ini terlihat sejak hari pertama sampai kedua, dimana jam istirahat sering kali tidak dimanfaatkan untuk istirahat, bahkan waktu sholat pun kami harus bergantian, karena banyak ibu dan bapak peserta yang bertanya, berdiskusi dan membicara kan rencana tindak lanjut setelah ini. Akhir sesi pelatihan dan workshop diisi dengan materi pemasaran dan membuat studi kelayakan bisnis, karena sebagai kegiatan lanjutan dari pengabdian masyarakat ini adanya pendampingan usaha dengan produk utama sayuran hidroponik.

Cara pembuatan pupuk organik yang disampaikan pada kegiatan ini adalah cara pembuatan pupuk organik cair yang kaya unsur Nitrogen $(\mathrm{N})$, pupuk organik cair yang kaya unsur Fosfor $(\mathrm{P})$, pupuk organik cair yang kaya unsur Kalium (K), dan pupuk organik padat (kompos bokashi). Pembuatan pupuk organik cair, dikutip dari Andoko (2002), yaitu semua bahan yang diperlukan untuk pembuatan pupuk cair maupun pupuk bokashi merupakan sumberdaya hayati yang didapatkan dari lingkungan sekitar peserta pelatihan sendiri.

Bahan-bahan yang digunakan dalam pembuatan pupuk $\mathrm{N}$ cair adalah daun salam 1 $\mathrm{kg}$, daun wedusan (Ageratum conyzoides) $1 \mathrm{~kg}$, air kelapa 1 liter, akar tanaman kacang tanah dengan bintilnya $1 \mathrm{~kg}$, EM-4 100ml, dan tetes tebu atau gula pasir 10 sendok makan. Cara pembuatannya yaitu dengan campuran daun salam, daun wedusan dan akar kacang tanah yang ditumbuk sampai halus, kemudian dimasukkan ke dalam ember dan ditambahkan air kelapa, EM-4, dan tetes atau gula pasir. Setelah itu ember ditutup rapat dan didiamkan selama 3 minggu, campuran tadi kemudian disaring dan digunakan hasil saringannya.

Bahan-bahan yang diperukan dalam pembuatan pupuk $\mathrm{P}$ cair antara lain batang pisang $1 \mathrm{~kg}$ dan juga $1 \mathrm{~kg}$ tetes atau nira. Batang pisang yang telah disediakan diris tipistipis, lalu dimasukkan ke dalam ember yang telah berisi tetes atau nira, ember ditutup 
rapat dan didiamkan selama 2 minggu. Setelah masa penyimpanan berakhir, batang pisang diremas-remas, disaring, dan hasil saringannya siap digunakan.

Untuk kegiatan pembuatan pupuk $\mathrm{K}$ cair, diperlukan sabut kelapa sebanyak $5 \mathrm{~kg}$ dan air 100 liter. Cara pembuatannya adalah; sabut kelapa dihancurkan dan dimasukkan ke dalam drum yang telah berisi air, ditutup rapat, dibiarkan selama 2 minggu, kemudian disaring dan larutannya siap digunakan.

Untuk pembuatan pupuk bokashi, diperlukan bahan rendeng (tanaman kacang tanah setelah dipanen) yang telah dicacah, tetes tebu dan EM-4. Semua bahan tersebut dicampur menjadi satu, ditumpuk di tempat terlindung, ditutup dengan karung goni, kemudian dibiarkan selama minimal 3 hari sambil terus dibolak-balik agar panasnya merata. Setelah kompos matang, terlihat dari wujud bahan dasar yang sudah tidak terlihat bentuk aslinya, warnanya juga kehitaman, dapat dipastikan pupuk bokashi sudah siap digunakan sebagai pupuk dasar. Sebagai pupuk dasar, maka pupuk ini baik digunakan setelah tanah selesai diolah dan siap ditanami.

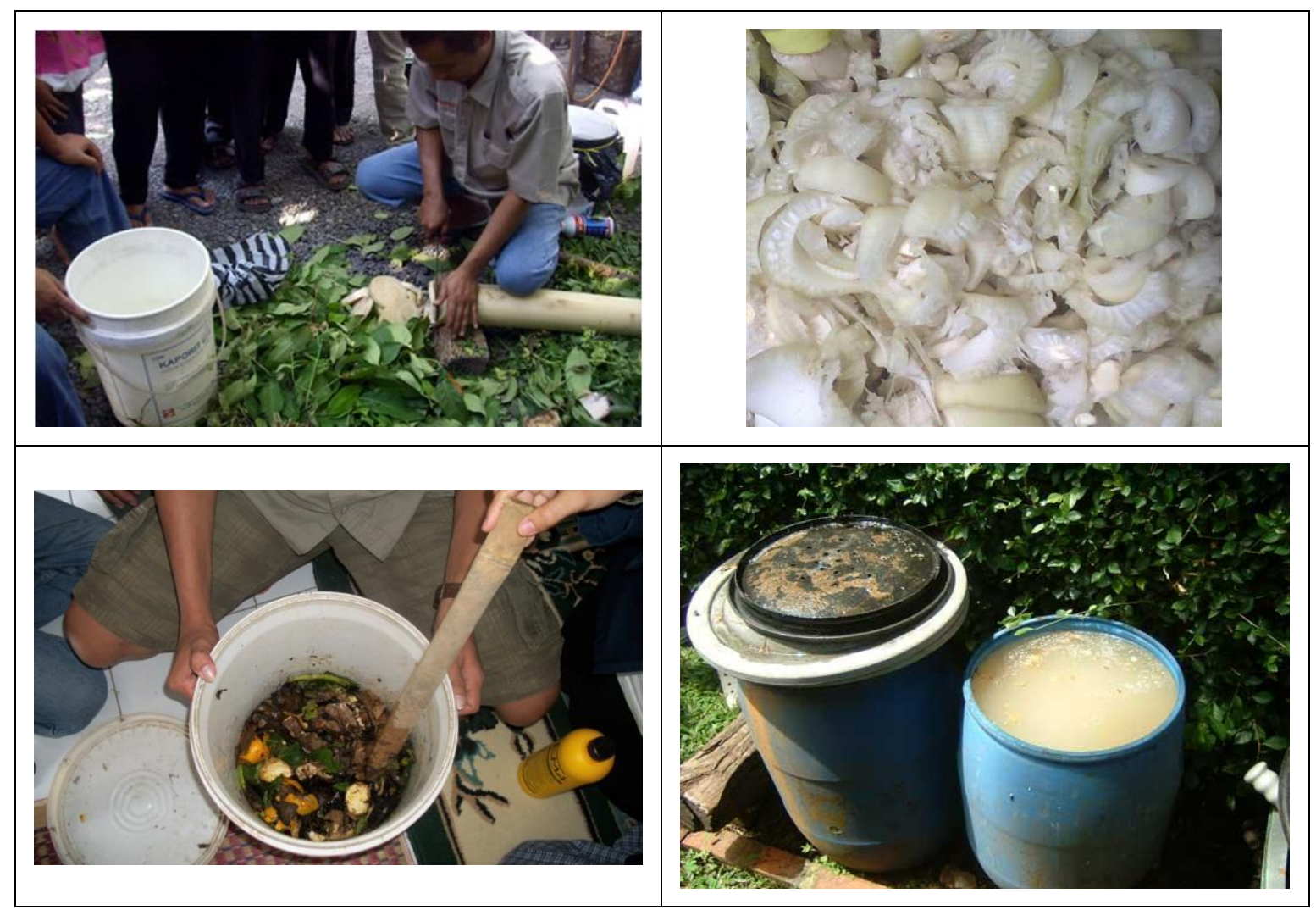

Gambar 4. Proses produksi pupuk organik bersama warga mitra.

\subsection{Pembahasan}

Setelah pelatihan dan workshop dilakukan dengan tujuan pemberdayaan masyarakat, kegiatan pada tahap selanjutnya adalah evaluasi kegiatan. Metode evaluasinya adalah dengan melakukan komparasi keterampilan, pengetahuan dan pemahaman peserta sebelum dan sesudah pelatihan meliputi cara bercocok tanam hidroponik, pembuatan pupuk maupun untuk materi kewirausahaan dan pemasaran produk. Peserta meyakini bahwa ketika lahan sempit mereka dimanfaatkan dengan baik dan maksimal, nantinya dapat menunjukkan hasil bagi produksi sayur sehat dan menambah pendapatan keluarga. Kegiatan ini secara umum memperlihatkan adanya peningkatan pengetahuan peserta, dimana saat praktik seluruh peserta dapat melakukan dengan mandiri, dapat merencanakan bisnis sederhana, serta dapat menjelaskan kembali saat diberi pertanyaan dalam sesi workshop bidang pemasaran. Pada Tabel 1 dibawah ini kita dapat melihat kriteria dan indikator keberhasilan kegiatan pengabdian masyarakat ini. 
Tabel 1 Indikator keberhasilan kegiatan

\begin{tabular}{|c|c|c|}
\hline No. & Kriteria & Indikator \\
\hline & $\begin{array}{l}\text { Tingkat } \\
\text { Partisipasi }\end{array}$ & $\begin{array}{l}\text { tingkat kehadiran peserta pada kegiatan pelatihan mencapai } 100 \% \text { sesuai } \\
\text { dengan jumlah undangan yang disebarkan. }\end{array}$ \\
\hline & $\begin{array}{l}\text { Seberapa jauh } \\
\text { peserta } \\
\text { memahami } \\
\text { materi pelatihan }\end{array}$ & $\begin{array}{l}\text { Terlihat pada munculnya peningkatan pemahaman mengenai teknik } \\
\text { penanaman hidroponik, kewirausahaan dan pemasaran. Peserta terlihat } \\
\text { aktif dalam kegiatan diskusi, tanya jawab, menyampaikan ide dan mampu } \\
\text { mempraktikkan dengan baik. Peserta terlihat serius serta antusias } \\
\text { mengikuti acara dari awal hingga selesai selama dua hari }\end{array}$ \\
\hline & $\begin{array}{l}\text { Dampak } \\
\text { Penyuluhan }\end{array}$ & $\begin{array}{l}\text { Peserta mampu mempraktikkan penanaman tumbuhan dengan cara } \\
\text { hidroponik, bisa meracik bahan-bahan yang diperlukan dalam membuat } \\
\text { pupuk organik, mampu merancang perencanaan bisnis sederhana dan } \\
\text { mempunyai ide tentang cara pemasaran untuk produk yang dihasilkan. }\end{array}$ \\
\hline & $\begin{array}{l}\text { Kesesuaian } \\
\text { materi }\end{array}$ & $\begin{array}{l}\text { Menurut pendapat peserta, materi pelatihan sangat kekinian } \\
\text { (hidroponik menjadi tren dan mampu menyediakan bahan pangan yang } \\
\text { organik). Cara penyampaian yang lugas dan komunikatif memudahkan } \\
\text { dan menarik peserta untuk mengikuti dan memahami materi wirausaha } \\
\text { dan marketing. }\end{array}$ \\
\hline
\end{tabular}

Secara umum kegiatan pengabdian ini berhasil jika dilihat dari beberapa indikator tersebut di atas, Ada beberapa indikator yang menjadi pendorong keberhasilan kegiatan ini, yaitu bahwa kegiatan ini dirancang dengan keterlibatan yang tinggi dari mitra pengabdian. Permasalahan yang diangkat dan diidentifikasi diperoleh secara langsung sehingga warga sangat antusias ketika mengikuti setiap tahap pengabdian masyarakat meskipun dengan jadwal yang padat. Sejalan dengan Kharisma dan Istiningsih (2017), dan Mega, Rizkillah, dan Irton (2017) yang menunjukkan bahwa metode pelatihan efektif dalam meningkatkan keterampilan dan juga pengetahuan mitra dalam melaksanakan teknologi yang diintroduksi.

Faktor yang menjadi penghambat adalah sarana untuk presentasi yang kurang baik, karena tidak tersedia layar stand untuk menampilan materi presentasi pada hari pertama dan cuaca yang gerimis sedikit mengganggu konsentrasi peserta. Waktu pelatihan dan workshop yang sangat terbatas, menjadikan peserta kurang puas saat melakukan praktik budidaya hidroponik dan praktik membuat rencana bisnis.

\section{KESIMPULAN}

Adapun kesimpulan dalam kegiatan pemberdayaan masyarakat adalah sebagai berikut.

1. Kegiatan pengabdian ini dapat menambah pengetahuan warga tentang pentingnya pemanfaatan lahan pekarangan melalui budidaya hidroponik dan produksi pupuk organik.

2. Warga mitra pengabdian sangat termotivasi menjadi wirausaha baru dibidang agribisnis tanaman hidroponik dan produsen pupuk organik.

3. Pada dasarnya warga mitra telah mulai memanfaatkan lahan pekarangan sempit mereka dengan tabulampot, sehingga kegiatan pelatihan difokuskan pada budidaya hidroponik, pengolahan pupuk organik yang dibuat dari limbah domestik warga, dan peningkatan wawasan tentang manajemen pemasaran dan kewirausahaan. 


\section{UCAPAN TERIMA KASIH}

Kegiatan pemberdayaan masyarakat ini melibatkan berbagai pihak yang mendukung baik moril maupun materiil, maka penulis menghaturkan banyak terima kasih kepada:

1. UPPM STKIP PGRI Tulungagung, yang menugaskan kami untuk menjalankan kegiatan Pemberdayaan Masyarakat Desa Sumberdadi dengan Pelatihan Hidroponik dan Pupuk Organik.

2. Pemerintahan desa dan masyarakat Desa Sumberdadi yang mendukung program Pemberdayaan Masyarakat Desa Sumberdadi dengan Pelatihan Hidroponik dan Pupuk Organik.

\section{DAFTAR PUSTAKA}

Andoko, A. 2008. Budidaya Padi Secara Organik. Jakarta: Penebar Swadaya

Ashari, S., dan Purwantini, T.B. (2012). Potensi dan Prospek Pemanfaatan Lahan Pekarangan Untuk Mendukung Ketahanan Pangan. Bogor: Pusat Sosial Ekonomi dan Kebijakan Pertanian.

Dwiratna, N.P.S., Widyasanti, A., dan Rahmah, D.M. (2016). Pemanfaatan Lahan Pekarangan Dengan Menerapkan Konsep Kawasan Rumah Pangan Lestari. Jurnal Aplikasi Untuk Masyarakat Dharmakarya, 5(1): 24-32.

Kharisma, R.S., dan Istiningsih. (2017). Ipteks bagi Masyarakat Taman Kanak-Kanak di Desa Kalitirto Kecamatan Berbah. JPP IPTEK, 1(1): 29-38.

Mega, W., Rizkillah, D., dan Irton. (2017). Ipteks bagi Masyarakat Produsen Tempurung Kelapa Desa Murangan. JPP IPTEK, 1(1): 39-46.

Roidah, I.S. (2014). Pemanfaatan Lahan Dengan Menggunakan Sistem Hidroponik. Jurnal Bonorowo, 1(2): 43-50.

Sarwono, E., Sutarmin, A., Ruhama, U., Suwarni, L., dan Selviana. (2018). PKM Inovasi Teknologi Produksi Olahan Ikan Pada Poklahsar Desa Kuala Secapah. JPP IPTEK, 2(2): 27-34. 